\title{
The Baetis vernus group (Ephemeroptera: Baetidae) of northernmost Europe: an evidently diverse but poorly understood group of mayflies
}

\author{
Eino Savolainen, Marcus K. Drotz, Per-Ola Hoffsten \& Anssi Saura
}

Savolainen, E., Drotz, M. K., Hoffsten, P.-O. \& Saura, A. 2007: The Baetis vernus group (Ephemeroptera: Baetidae) of northernmost Europe: an evidently diverse but poorly understood group of mayflies. — Entomol. Fennica 18: 160 167.

The Baetis vernus group is known to be a taxonomically difficult group of mayflies. Morphological characters such as the mandibles or gills of nymphs overlap widely. We report here that enzyme electromorph frequencies also fail to show reproductive isolation in many cases. Baetis macani has been divided in the literature into two forms, a lentic one with broader gills living in stagnant waters, while the lotic one with narrower gills lives in flowing water. We show that the two evidently represent reproductively isolated taxa, $B$. macani Kimmins $=B$. bundyae auct. nec, while the one with broader gills appears to be a new species. Baetis macani, B. subalpinus, B. liebenauae and $B$. vernus form a cluster that is genetically not divisible according to the recognized species boundaries. Nymph gill length differentiates, however, B. macani from B. subalpinus and $B$. vernus. We call for studies on population structuring and molecular taxonomy to resolve the taxonomy and ecology of this important group of mayflies.

E. Savolainen, Kuopio Natural History Museum, Myhkyrinkatu 22, FI-70100 Kuopio, Finland; E-mail eino.savolainen@kuopio.fi

M. K. Drotz, Lake Vänern Museum of Natural and Cultural History, SE-53154 Lidköping, Sweden; E-mailmarcus.drotz@lidkoping.se

P.-O. Hoffsten, Pelagia Miljökonsult AB, Strömpilsplatsen 12 - Sjöbod 2, SE-907

43 Umeå, Sweden; E-mail per-ola.hoffsten@pelagia.se

A. Saura, Department of Molecular Biology, Umeå university, SE-901 87 Umeå, Sweden; E-mailanssi.saura@molbiol.umu.se

Received 12 September 2006, accepted 25 October 2006

\section{Introduction}

The genus Baetis is geographically widespread and many species are abundant, in particular in northernmost Europe. Because the adult stage is short, nymphs are the most easily collected and biologically the most interesting stage in the life cycle. Baetis nymphs are now extensively used in biomonitoring of environmental quality (e.g. Fialkowski et al. 2003).

Linnaeus (Linné 1767, p. 901) recognized the difficulties inherent in assigning the short-lived mayfly adults to species. The adults and nymphs of the northern European representatives of the vernus group (Müller-Liebenau 1969) of Baetis are difficult indeed to separate morphologically. 
For a broader overview on the relationships within Baetis the reader is referred to Jacob (2003). Engblom (1996) gives an authoritative key to the species but when one is examining field-caught material there is much geographical and ecological variation in characters. To give an example, Bauernfeind and Humpesch (2001) reviewed the central European fauna. They note that the gills of B. macani, vernus and tracheatus nymphs are considerably longer when they live in lake and pond habitats in comparison with flowing water.

The vernus group Müller-Liebenau (1969) comprises the following north European species:

Baetis vernus Curtis 1834 exhibits much morphological variation (Engblom 1996). It has a wide transpalearctic distribution. The nymphs live in flowing water (Müller-Liebenau 1969, Jacob 2003).

Baetis subalpinus Bengtsson 1917 is a northern species that has not been found outside of Fennoscandia. In northern Sweden the nymphs live in water flowing with intermediate velocity (Müller-Liebenau 1969, Jacob 2003).

B. macani Kimmins 1957 was originally described from Finnish Lapland from an arctic/alpine pond (Kimmins 1957). Macan (1957) described the nymphs from the same pond and, in addition, from two large lakes from central Finland and central Sweden. The nymphs live both in lentic and lotic habitats, typically at outflows from lakes (Jacob 2003).

Baetis bundyae auct. nec is a northern European form with narrow gills. Engblom (1996) gives small ponds above the tree line as the typical habitat in Europe. Baetis bundyae Lehmkuhl 1973 was described from tundra ponds in arctic Canada. It has also been recorded in flowing water elsewhere in arctic Canada (e.g. Cobb \& Flannagan 1980, Harper \& Harper 1997) and has a distribution extending south along the Rocky Mountains. Morihara and McCafferty (1979) designated the Canadian Baetis bundyae Lehmkuhl as a subspecies of the European $B$. macani. The subspecific status is based on geographical isolation, North America versus Europe; the morphological variation is subject to "overlapping character states between the two subspecies". There is certainly much overlap inside Europe and ecological confusion as well. To give an example, Degerman et al. (1994) give separate distribution maps for $B$. bundyae, B. macani and B. macani-bundyae in Sweden.

Baetis liebenauae Keffermüller 1974 was described from the river Odra in western Poland (Keffermüller 1974). In Fennoscandia it was first recorded from southernmost Sweden in 1979 (Engblom 1996) and from northern Finland by Savolainen and Pulkkinen (1987). It has a distribution covering almost all of Europe and Asia Minor. All records come from flowing water (Jacob 2003).

Baetis tracheatus Keffermüller \& Machel 1967 was described from Poland (Keffermüller \& Machel 1967). Savolainen and Saura (1996) reported it from northern Finland. Both in Poland and elsewhere in Europe the nymphs live in lakes and slowly flowing water among water plants (Müller-Liebenau 1969, Jacob 2003).

In addition, we have used nymphs of Baetis rhodani Pictet 1843-1845, B. niger (Linnaeus 1761) and Acentrella lapponica (Baetis lapponicus) Bengtsson 1912 as an outgroup. Within the genus Baetis, $B$. rhodani belongs to the subgenus Rhodobaetis and B. niger to the subgenus Nigrobaetis (Jacob 2003).

The existing keys for larvae are not always useful. We use here enzyme electrophoresis and allele frequencies as a criterion of reproductive isolation. Using an extensive material covering several years, we aim at seeing whether the nymph forms found in northernmost Europe represent bona species. Specifically, we wish to find out whether the lotic and lentic forms assigned to a single species are conspecific and represent phenotypic responses to different environmental conditions or whether there are one or several ecologically isolated species and whether the nymph forms assigned to different species in a single habitat represent reproductively isolated entities.

\section{Material and methods}

The author Savolainen collected mayfly nymphs from the localities shown in Fig. 1 in northern Finland. Table 1 gives the names of the species, the names of the localities, the days when collected and the numbers of individuals assayed by 


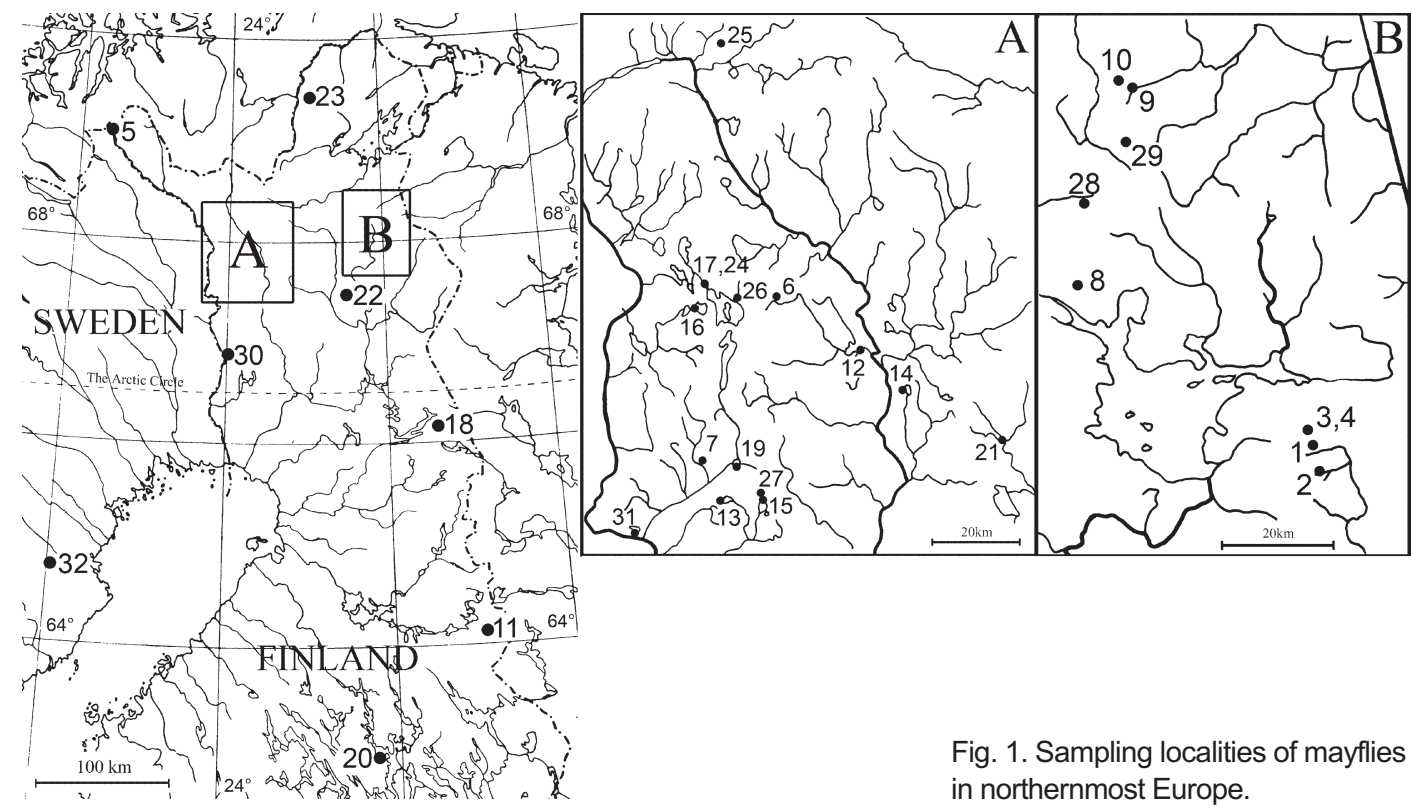

electrophoresis. In addition, the author Hoffsten collected nymphs from a locality from which Engblom had collected on 5.VII.1980 and had identified as Baetis macani with broad gills at Lake Bastuträsk, Västerbotten, Sweden (this is sample number 50 in the Table 1). The nymphs were kept in deep freeze until assayed for starch gel electrophoresis. The nymphs were assigned to species following the key of Engblom (1996), which relies on mandibles in particular. Nymph mandibles are subjected to wear, a circumstance that makes species identification difficult (see the discussion section for details).

The electrophoretic methods are described by Savolainen et al. (1993). The following enzymes gave repeatable results: acid phosphatase (Acph), esterases (Est), glutamate oxaloacetate transaminase (Got), Peptidase (Pep), phosphoglucose isomerase (Pgi) and Triosephosphate isomerase (Tpi). In addition, all systems mentioned by Savolainen et al. (1993) were tried but the remainder was regarded as insufficiently repeatable or they were monomorphic in all species studied here. Samples from different populations were run on the same gel so that the samples served as controls to each other.

To get an overview of the extensive temporal and spatial variation disclosed with enzyme electrophoresis, one needs a method to visualize the results obtained from different gene pools. The neighbour-joining algorithm of Saitou and Nei (1987) is particularly suited for analyzing this kind of large data set. It does not assume constant rates of evolution and approximates the minimum evolution method (Page \& Holmes 1998). The unbiased genetic distance of Nei (1978) was chosen as clustering algorithm. Phenogram construction was done using Version 1.0 of the GDA program (Lewis \& Zaykin 1996). We have only included populations that gave repeatable results over the set of enzyme systems in constructing the phenogram.

We revise the species names in the discussion section. To avoid confusion, we use the revised names in the results.

\section{Results}

Distinguishing Baetis species on morphological criteria has been notoriously difficult. This difficulty is also reflected in the genetic differentiation: one can not recognize clear-cut species boundaries among $B$. subalpinus, $B$. vernus, $B$. liebenauae, B. tracheatus and B. macani (Fig. 2). The lentic form of Baetis macani with narrow gills had only moderate but consistent frequency differences against the lotic form with broad gills. 
Table 1. Sample number, Baetis species name, site number (water course, parish, coordinates according to the uniform grid system), habitat $(B=$ brook, $R=$ river, $L=$ lake), collecting date, and number of nymphs sampled.

\begin{tabular}{|c|c|c|c|c|c|}
\hline 1 & macani & 1 Paskalomaoja, Savukoski, 7532:549 & B & 5 August 1996 & 30 \\
\hline 2 & macani & 1 Paskalomaoja, Savukoski, 7532:549 & B & 5 August 1997 & 18 \\
\hline 3 & macani & 2 Sarakko-oja, Savukoski, 7529:551 & B & 5 August 1997 & 14 \\
\hline 4 & macani & 3 Parakainen, headwater, Savukoski, 7535:550 & B & 5 August 1997 & 10 \\
\hline 5 & macani & 4 Parakainen, Savukoski, 7534:549 & B & 5 August 1997 & 7 \\
\hline 6 & macani & 5 Ahdaskuru, Enontekiö, 7678:251 & B & 8 August 1997 & 7 \\
\hline 7 & macani & 3 Parakainen, headwater, Savukoski, 7535:550 & B & 8 August 1998 & 20 \\
\hline 8 & macani & 6 Pälkevaara, Kittilä, 7539:389 & B & 10 August 1998 & 21 \\
\hline 9 & macani & 8 Pauttiselkä, Sodankylä, 7558:510 & B & 22 July 1999 & 20 \\
\hline 10 & macani & 9 Lutto, Inari, 7593:518 & B & 23 July 1999 & 23 \\
\hline 11 & macani & 10 Kaunispäänoja, Inari, 7595:516 & B & 24 July 1999 & 24 \\
\hline 12 & lapponica & 5 Ahdaskuru, Enontekiö, 7678:251 & B & 8 August 1997 & 18 \\
\hline 13 & lapponica & 12 Myllyjoki, Kittilä, 7527:407 & $\mathrm{R}$ & 5 August 1995 & 15 \\
\hline 14 & liebenauae & 11 Niemisjoki, I rapids, Kuhmo, 7115:650 & $\mathrm{R}$ & 7 August 1998 & 38 \\
\hline 15 & liebenauae & 12 Myllyjoki, Kittilä, 7527:407 & $\mathrm{R}$ & 10 August 1998 & 6 \\
\hline 16 & sp. nov. & 13 Luosujärvi, Kolari, 7495:376 & $\mathrm{L}$ & 3 August 1995 & 27 \\
\hline 17 & sp. nov. & 14 Riikonjärvi, Kittilä, 7519:417 & L & 4 August 1995 & 19 \\
\hline 18 & sp. nov. & 15 Ylläsjärvi, Kolari, 7495:385 & L & 5 August 1995 & 23 \\
\hline 19 & sp. nov. & 16 Särkijärvi, Muonio, 7538:371 & L & 6 August 1995 & 62 \\
\hline 20 & sp. nov. & 17 Törmäslommol, Muonio, 7543:374 & $\mathrm{L}$ & 6 August 1995 & 30 \\
\hline 21 & sp. nov. & 18 Rukajärvi, Kuusamo, 7340:599 & L & 2 August 1996 & 30 \\
\hline 22 & sp. nov. & 19 Äkäslompolo, Kolari, 7505:378 & L & 7 August 1997 & 29 \\
\hline 23 & sp. nov. & 20 Kallavesi, Kuopio, 6977:531 & $\mathrm{L}$ & 6 August 1998 & 10 \\
\hline 24 & sp. nov. & 22 Kelujärvi, Sodankylä, 7487:501 & $\mathrm{L}$ & 27 July 1999 & 30 \\
\hline 25 & niger & 11 Niemisjoki, Kuhmo, 7115:650 & $\mathrm{R}$ & 7 August 1998 & 3 \\
\hline 26 & rhodani & 23 Karigasniemi, Utsjoki, 7702:463 & B & 3 July 1997 & 20 \\
\hline 27 & rhodani & 11 Niemisjoki, Kuhmo, 7115:650 & $\mathrm{R}$ & 7 August 1998 & 3 \\
\hline 28 & rhodani & 7 Hillajänkänoja, Kolari, 7503:373 & B & 21 July 1999 & 20 \\
\hline 29 & subalpinus & 12 Myllyjoki, Kittilä, 7527:407 & $\mathrm{R}$ & 5 August 1995 & 11 \\
\hline 30 & subalpinus & 24 Kutuniva, Muonio, 7543:374 & $\mathrm{R}$ & 6 August 1995 & 10 \\
\hline 31 & subalpinus & 25 Markkajoki, Enontekiö, 7598:379 & $\mathrm{R}$ & 7 August 1995 & 7 \\
\hline 32 & subalpinus & 11 Niemisjoki, Kuhmo, 7115:650 & $\mathrm{R}$ & 3 July 1997 & 13 \\
\hline 33 & subalpinus & 11 Niemisjoki, Kuhmo, 7115:650 & $\mathrm{R}$ & 7 August 1998 & 20 \\
\hline 34 & subalpinus & 26 Keimiö-oja, Kittilä, 7540:380 & B & 10 August 1998 & 34 \\
\hline 35 & subalpinus & 12 Myllyjoki, Kittilä, 7527:407 & $\mathrm{R}$ & 10 August 1998 & 7 \\
\hline 36 & subalpinus & 27 Torpanoja, Kolari, 7495:385 & B & 10 August 1998 & 36 \\
\hline 37 & subalpinus & 21 Jeesiöjoki, Kittilä, 7508:438 & $\mathrm{R}$ & 22 July 1999 & 3 \\
\hline 38 & subalpinus & 28 Ylisenoja, Sodankylä, 7572:509 & $\mathrm{R}$ & 27 July 1999 & 10 \\
\hline 39 & subalpinus & 29 Kiilo-oja, Sodankylä, 7583:517 & B & 27 July 1999 & 8 \\
\hline 40 & tracheatus & 21 Jeesiöjoki, Kittilä, 7508:438 & $\mathrm{R}$ & 2 August 1995 & 42 \\
\hline 41 & tracheatus & 21 Jeesiöjoki, Kittilä, 7508:438 & $\mathrm{R}$ & 3 August 1996 & 10 \\
\hline 42 & tracheatus & 21 Jeesiöjoki, Kittilä, 7508:438 & $\mathrm{R}$ & 6 August 1997 & 22 \\
\hline 43 & tracheatus & 21 Jeesiöjoki, Kittilä, 7508:438 & $\mathrm{R}$ & 9 August 1998 & 20 \\
\hline 44 & vernus & 30 Orankijoki, Pello, 7427:373 & $\mathrm{R}$ & 2 August 1995 & 30 \\
\hline 45 & vernus & 21 Jeesiöjoki, Kittilä, 7508:438 & $\mathrm{R}$ & 2 August 1995 & 17 \\
\hline 46 & vernus & 21 Jeesiöjoki, Kittilä, 7508:438 & $\mathrm{R}$ & 3 August 1996 & 10 \\
\hline 47 & vernus & 21 Jeesiöjoki, Kittilä, 7508:438 & $\mathrm{R}$ & 6 August 1997 & 20 \\
\hline 48 & vernus & 21 Jeesiöjoki, Kittilä, 7508:438 & $\mathrm{R}$ & 9 August 1998 & 20 \\
\hline 49 & vernus & 31 Mannajoki, Kolari, 7489:357 & B & 21 July 1999 & 8 \\
\hline 50 & vernus & 21 Jeesiöjoki, Kittilä, 7508:438 & $\mathrm{R}$ & 22 July 1999 & 10 \\
\hline 51 & undescribed & 32 Bastuträsk, Skellefteå, 719900:169900 & $\mathrm{L}$ & 25 July 1998 & 10 \\
\hline
\end{tabular}




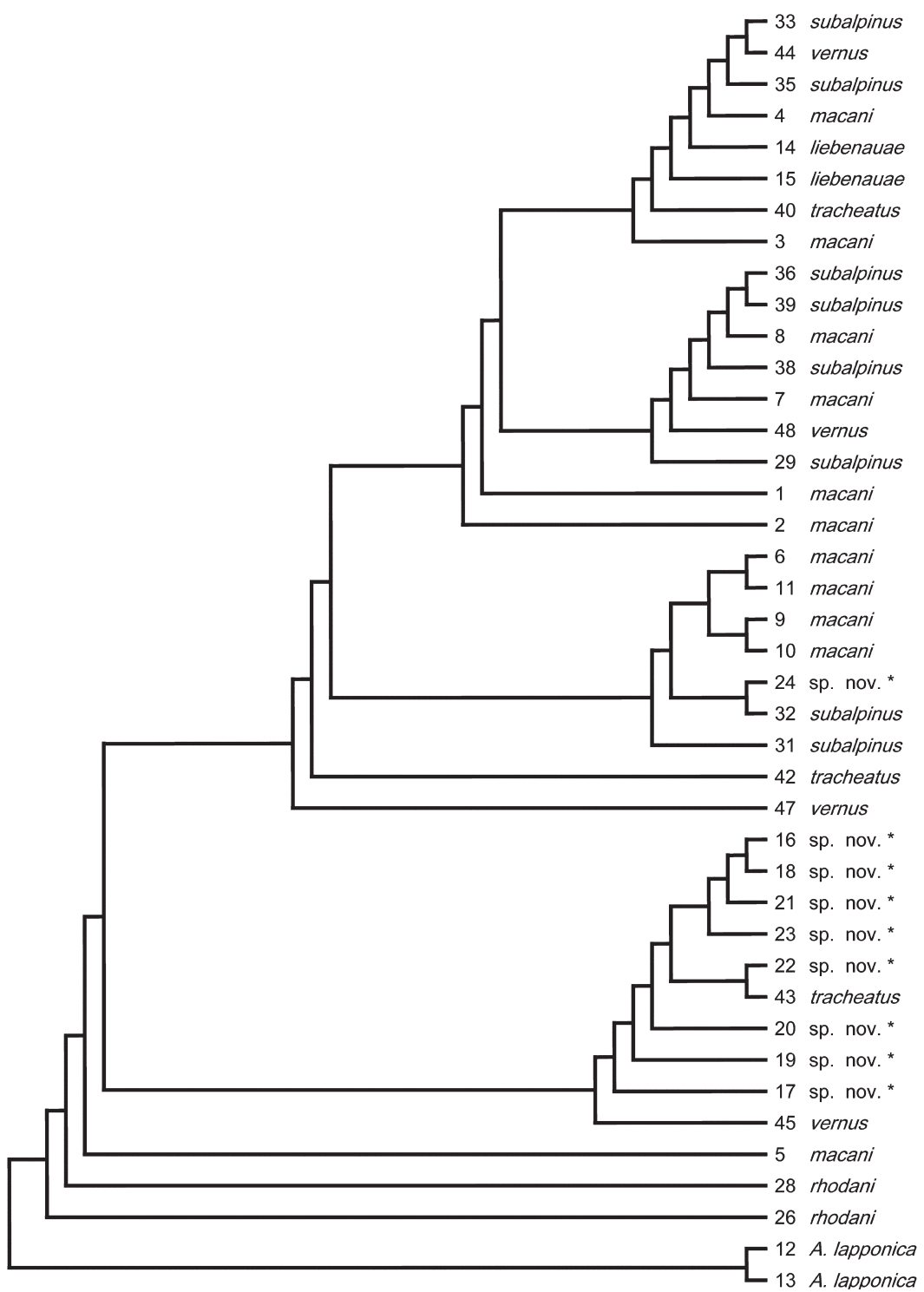

Fig. 2. A neighbour-joining phenogram based on the clustering algorithm of Nei (1978) showing genetic distances among the populations studied, based on the allelic variation at the enzyme loci studied (see the electronic appendix, Drotz et al. 2006 for allele frequencies). Note that some populations are excluded from the phenogram, mainly because of small sample size or the lack of data for a certain enzyme system. * undescribed species, see text.

In contrast to the overall quite diffuse allelic differentiation seen in other Baetis taxa, the form with broad gills has a clearly circumscribed gene pool. Therefore we designate it here as sp. nov. Accordingly, the two macani forms represent reproductively isolated taxa. The allele frequency data are available in the form of an electronic appendix (Drotz et al. 2006).

Nevertheless, within the $B$. vernus group one could observe certain clear-cut genetic differences. The Myllyjoki population number 29 morphologically identified to be $B$. subalpinus was fixed for a rare allele at Tpi that differed from the one seen in other samples from the same locality (12). The locus is in general monomorphic within a species and different alleles fixed at nearby populations indicate reproductive isolation. The Bastuträsk sample from central Sweden (site 32) also differed from the northern Finnish ones far more than the Kallavesi population from central Finland did, even though geographically it was closer to the northern samples. Baetis tracheatus had allele frequencies indistinguishable from sp. nov. in one case.

Outside of the $B$. vernus group one locus or two loci were often almost or completely fixed 
for species-specific alleles that, accordingly, can be used as species diagnostic characters. Acentrella lapponica differs from the others at the Acph and Pgi loci. It has the allele 85 fixed in Pgi, while all other species but $B$. rhodani have very low frequencies of this allele. The sample of $B$. niger was small indeed, but the three individuals had species-specific alleles fixed at Est-2, Pep and Tpi loci. Baetis rhodani differs from the others at Acph and Pgi.

\section{Discussion}

\subsection{A complex without distinct species boundaries?}

Baetis vernus group is known to be a morphologically difficult cluster of species (Müller-Liebenau 1969 , Jacob 2003). This difficulty is also seen in the allele frequency data generated by enzyme electrophoresis (Drotz et al. 2006). We may take as an example the large temporal variation in $B$. tracheatus from the same locality (21) sampled in 1995, 1997 and 1998. One sample (43) is very close to the sp. nov., while two others (40 and 42) cluster with $B$. macani and $B$. liebenauae. In contrast, the samples of sp. nov. come from an extensive area.

Baetis macani, B. subalpinus and $B$. vernus cluster with each other. They all come from flowing water. The electrophoretic methods that we have used do not show consistent allele frequency differences that would follow the slight morphological differences that characterize these taxa. Morphologically B. macani has consistently long gills and is a rather coherent taxon in comparison to $B$. subalpinus and $B$. vernus, which show character overlap (cf. Bauernfeind \& Humpesch 2001, Engblom, pers. comm.). Species discrimination is based mainly on mandibles, even though Müller-Liebenau (1969) had pointed out that characters such as surface of tergites, epicranial sutures, bristles of femora etc. can be useful. We have observed that patterns of mandibular wear vary among individual nymphs, this again may be site specific. Müller-Liebenau (pers. comm.) has stressed that because of wear, one should not look at the mandibles in use but at the next, unused pair that is visible under the nymphal cuticle.

The small genetic differentiation between $B$. macani/subalpinus/vernus that we have observed may be a consequence of introgression, i.e gene flow across species boundaries. We have studied only nymphs. The short-lived adults are, however, the agents of reproductive isolation. Baetis adults swarm in July-August over low vegetation in a vertical fashion from 0.5 up to $4 \mathrm{~m}$ from the ground from afternoon until evening. The males will try to mate with about everything that flies in the vicinity (Savolainen 1978). They swarm close to the water, where the nymphs live, so that swarming either next to flowing or stagnant water results in ethological isolation. Savolainen et al. (1993) have shown that swarming behaviour is associated with genetic differentiation in mayflies.

On the other hand, local selection such as water velocity (Bauernfeind \& Humpesch 2001) could be expected to modify the flexible nymph morphology. Molecular studies using both mtDNA and nuclear markers would help solving these issues. Williams et al. (2006) have, using the CO1 gene of mitochondrial DNA found that Baetis rhodani is made up of a complex of cryptic species. In our opinion their results strengthen the conclusions that we have reached here: there is much ecological and geographic differentiation going on among Baetis mayflies.

The pattern of genetic differentiation in Baetis mayflies has been studied within and among river systems (Monaghan et al. 2001, 2002, Hughes et al. 2003). Their studies were made in alpine environments that could be thought to give rise to geographic isolation between drainages. In spite of this, the levels of genetic differentiation were in general low. This agrees with our results: allele frequencies were quite uniform within a species over geographic distances larger than the ones in the above studies.

One may observe a horizontal pattern of allele frequency similarities among species at a single locality, as shown by the $B$. liebenauae sample 14 and $B$. subalpinus sample 32 from site 11 . We tried to get samples from the same sites in order to study sympatric populations and sampled the sites repeatedly. Nevertheless, $B$. macani and sp. nov. populations are not found to be sympatric. 


\subsection{What is Baetis macani Kimmins?}

Gill length is thought to be correlated with water flow in the environment, where the Baetis nymphs live. In stagnant water the size of gills is larger than in flowing water (Bauernfeind \& Humpesch 2001). Baetis macani with broader gills and conspicuous tracheae lives in stagnant water (Savolainen \& Saaristo 1981). Now it is evident that this lentic form is a new species; here called sp. nov. The formal species description will be given in a separate publication.

Our results show that north European $B$. macani (as recognized by Savolainen \& Saaristo 1981) with narrower gills consistently clusters separate from the forms with broader gills (Fig. 2). The lotic form with narrower gills is identical with $B$. macani Kimmins since the nymph characters agree with the description of Macan (1957). We note that the nymph characters given by Lehmkuhl (1973) for the North American $B$. bundyae also agree with the description given by Macan (1957) for B. macani. Morihara \& McCafferty (1979) pointed out that there are no consistent differences between $B$. macani and $B$. bundyae that would warrant a species status for B. bundyae.

\subsection{Conclusions}

Evidently more work is needed before we understand the taxonomy and ecology in this important group of mayflies. Phylogenetic methods tied to DNA analysis and F-statistics may solve much of the confusing overlap in morphological characters and give us a good taxonomic understanding and good species designation that can be used in the ecological studies. Degerman et al. (1994) stressed that there certainly are difficulties in recognizing the different forms when one is using Baetis in monitoring water quality.

Acknowledgements. The author Savolainen thanks the Finnish Ministry of Environment for financial support within a project involved in mapping threatened animal species in Finland and the author Saura thanks the Natural Sciences Research Council of Sweden. Dr. Pertti Renvall has helped us to solve technical and theoretical questions. We wish to thank Eva Engblom for encouragement, continuous support and help in determining mayflies and
Astrid Höglund, Jukka Tuononen and Arja Pulkkinen for technical assistance.

\section{References}

Bauernfeind, E. \& Humpesch, U. H. 2001: Die Eintagsfliegen Zentraleuropas (Insecta: Ephemeroptera): Bestimmung und Ökologie. — Wien: Verlag des Naturhistorischen Museums Wien. 239 pp.

Cobb, D. G. \& Flannagan J. F. 1980: The distribution of Ephemeroptera in northern Canada. - In: Flannagan, J. F. \& Marshall, K. E. (ed.), Advances in Ephemeroptera biology: 155-166. Plenum Press, New York. $552 \mathrm{pp}$.

Degerman, E., Fernholm, B., Lingdell, P.-E. 1994: Bottenfauna och fisk i sjöar och vattendrag (in Swedish). Naturvårdsverket, rapport 4345, Solna. 201 pp.

Drotz, M. K., Saura, A., Hoffsten, P.-O. \& Savolainen, E. 2006: Supplementary material to Savolainen, E., Drotz, M. K., Hoffsten, P.-O. \& Saura, A. 2006: The Baetis vernus group Ephemeroptera, Baetidae) of northernmost Europe: an evidently diverse but poorly understood group of mayflies. [www-document] URL http://www.kuopionluonnontieteellinenmuseo.fi/publications.

Engblom, E. 1996. Ephemeroptera (Mayflies). — In: Nilsson, A. N. (ed.), The aquatic insects of North Europe: 13-53. Apollo Books, Stenstrup. 274 pp.

Fialkowski, W., Klonowska-Olejnik, M., Smith, B. D. \& Rainbow, P. S. 2003: Mayfly larvae (Baetis rhodani and $B$. vernus) as biomonitors of trace metal pollution in streams of a catchment draining a zinc and lead mining area of Upper Silesia, Poland. - Environ. Pollut. 121: 253-267.

Harper, P. \& Harper, F. F. 1997: Mayflies (Ephemeroptera) of the Yukon. - In: Danks, H. W. \& Downes, J. A. (ed.), Insects of Yukon. Biological survey of Canada (Terrestrial Arthropods): 151-168. Canadian Museum of Nature, Ottawa.

Hughes, J. M., Mather, P. B., Hillyer, M. J, Cleary, C. \& Peckarsky, B. 2003: Genetic structure in montane mayfly Baetis bicaudatus (Ephemeroptera: Baetidae), from the Rocky Mountains, Colorado. - Freshwater Biol. 48: 2149-2162.

Jacob, U. 2003: Baetis Leach 1815, sensu stricto oder sensu lato. Ein Beitrag zum Gattungskonzept auf der Grundlage von Artengruppen mit Bestimmungsschlüsseln. — Lauterbornia 47: 59-129.

Keffermüller. M. 1974: A new species of the genus Baetis Leach (Ephemeroptera) from western Poland. - B. Acad. Pol. Sci., Sér. Sci. Biol Cl II 22: 183-185.

Keffermüller, M. \& Machel M. 1967: Baetis tracheatus, sp. n. (Ephemeroptera, Baetidae). — Bad. Fizjograf. Pol. Zach. 20: 11-14.

Kimmins, D. E. 1957: A new species of the genus Baëtis (Ephemeroptera) from North Finland. - Notul. Entomol. 37: 27-29.

Lehmkuhl, D. M. 1973. A new species of Baëtis (Epher- 
meroptera) from ponds in the Canadian arctic, with biological notes. - Can. Entomol. 105: 343-346.

Lewis, P. O. \& Zaykin, D. 1996: GDA(Genetic data analysis). - In: Weir, B. (ed.), Genetic data analysis II: 91138. Sinauer Associates, San Francisco.

Linné C. 1767. Systema naturae, Tom. I, Pars II, XIIth Ed.: p. 901. Laurentius Salvius, Stockholm.

Macan, T. T. 1957. A description of the nymph of Baëtis macani Kimmins. - Notul. Entomol. 37: 58-60.

Monaghan, M. T., Spaak, P., Robinson, C. T. \& Ward, J. V. 2001: Genetic differentiation of Baetis alpinus Pictet (Ephemeroptera: Baetidae) in fragmented alpine streams. - Heredity 86: 395-403.

Monaghan, M. T., Spaak, P., Robinson, C. T. \& Ward, J. W. 2002: Population genetic structure of 3 alpine stream insects: influences of gene flow, demographics, and habitat fragmentation. - J. N. Am. Benthol. Soc. 21: 114-131.

Morihara, D. K. \& McCafferty, W. P. 1979: Subspecies of the transatlantic species, Baetis macani (Ephemeroptera: Baetidae). - P. Entomol. Soc. Wash. 81: 3437.

Müller-Liebenau, I. 1969: Revision der europäischen Arten der Gattung Baetis Leach, 1815 (Insecta, Ephemeroptera). — Gewässer/Abwässer 48/49: 1-214.

Nei, M. 1978. Estimation of average heterozygosity and genetic distance from a small number of individuals. - Genetics 23: 341-369.
Page, R. D. M. \& Holmes, E. C. 1998. Molecular evolution: a phylogenetic approach. Blackwell, Oxford. 346 pp.

Saitou, N. \& Nei, M. 1987. The neighbor-joining method: a new method for reconstructing phylogenetic trees. Mol. Biol. Evol. 4: 406-425.

Savolainen, E. 1978: Swarming in Ephemeroptera: the mechanism of swarming and the effects of illumination and weather. - Ann. Zool. Fenn. 15: 17-52.

Savolainen, E. \& Pulkkinen, A. 1987: The mayflies (Ephemeroptera) of Kainuu (Ok), Finland. - Kulumus 9: 4-35.

Savolainen, E. \& Saaristo, M. 1981: Distribution of mayflies (Ephemeroptera) in the biological province of Kuusamo (Ks), Finland. — Notul. Entomol. 61: 117124.

Savolainen, E. \& Saura, A. 1996: Baetis tracheatus Keffermüller \& Machel (Ephemeroptera, Baetidae), the first record in Finland; found in an eutrophic Stratiotes-river in Kittilä. — Sahlbergia 3: 28-29.

Savolainen, E., Saura, A. \& Hantula, J. 1993: Mode of swarming in relation to reproductive isolation in mayflies. - Evolution 47: 1796-1804.

Williams, H. C., Ormerod, S. L. \& Bruford, M.W. 2006 : Molecular systematics and phylogeography of the cryptic species complex Baetis rhodani (Ephemeroptera, Baetidae). - Mol. Phylogenet. Evol. 40: 370 382. 